\title{
Status kesehatan mulut dan asupan makan sebagai faktor risiko underweight pada lansia
}

\author{
Oral health status and dietary intake as risk factors for underweight in elderly
}

Dian Isti Angraini', Al Supartinah², Deddy Nur Wachid ${ }^{3}$

\begin{abstract}
Background: Oral health status and dietary intake contribute to nutritional status in elderly. Missing teeth cause chewing disorder that reduces quality and quantity of food intake, which finally makes the elderly have underweight nutritional status. Objective: To determine the risk factors for underweight in the elderly at Yogyakarta Municipality.

Method: The study was observational with case control design on elderly at Yogyakarta Municipality. Subjects consisted of 210 elderly matched in age and gender. Sampling was done by multistage random sampling. Oral health status was assessed through dental health status (index of missing teeth) and periodontal status (gingival index, periodontal index and oral hygiene index), dietary intake was collected by using semi quantitative food frequency questionnaire (SQ-FFQ) and underweight nutritional status was based on body mass armspan (BMA). Data were analyzed by using tests of $X^{2}$ Mc. Nemar, $X^{2}$ Stuart Maxwell, and conditional logistic regression.

Results: Bivariate analysis showed the number of missing teeth $\geq 21(O R=3.67, p<0.05)$ and $16-20(O R=3.53, p<0.05)$ as risk factors of underweight, whereas the gingival index, periodontal index and oral hygiene index were not. Less intake of energy $(O R=6.3)$, protein $(O R=7.83)$, fat $(O R=5.67)$ and carbohydrates $(O R=7.5)$ were risk factors of underweight $(p<0.01)$. Income less than $R p$ 808.000,00 was also risk factor for underweight $(O R=4.5 ; p<0.01)$. Multivariate analysis showed the significant risk factors for underweight were the missing teeth $\geq 21(O R=8.76)$ and 16-20 $(O R=6.04)$ which increased by income less than $R p$ 808.000,00 (OR=5.94), less fat intake (OR=4.88), and less carbohydrate intake $(O R=5.48)$. Income was confounding factor in the risk of missing teeth and protein intake for becoming underweight.

Conclusion: Significant risk factors of underweight in elderly were missing teeth $\geq 16$, less intake of fat and carbohydrate, and income less than $\mathrm{Rp} 808.000,00$
\end{abstract}

KEY WORDS: elderly, underweight, oral health status, dietary intake

\begin{abstract}
ABSTRAK
Latar belakang: Status kesehatan mulut dan asupan makan berkontribusi terhadap status gizi lansia. Kehilangan gigi menyebabkan gangguan pengunyahan sehingga menurunkan kualitas dan kuantitas asupan makanan, yang pada akhirnya menyebabkan lansia berstatus gizi underweight.

Tujuan: Mengetahui faktor-faktor risiko underweight pada lansia di Kota Yogyakarta.

Metode: Penelitian ini merupakan penelitian observasional dengan rancangan case control. Subjek penelitian berjumlah 210 orang dengan matching umur dan jenis kelamin. Pengambilan sampel dilakukan secara multistage random sampling. Status kesehatan mulut dinilai berdasarkan indeks status kesehatan gigi (indeks M-T/ jumlah kehilangan gigi) dan indeks status periodontal (indeks gingiva, indeks periodontal, dan indeks kebersihan mulut), asupan makan dikumpulkan dengan semi quantitative food frequency questionnaire (SQ-FFQ), dan status gizi underweight ditentukan berdasarkan body mass armspan (BMA). Data dianalisis dengan uji $X^{2}$ Mc.Nemar, $X^{2}$ Stuart Maxwell, dan conditional logistic regression.

Hasil: Analisis bivariat menunjukkan jumlah kehilangan gigi $\geq 21(O R=3,67 ; p<0,05)$ dan 16-20 $(O R=3,53 ; p<0,05)$ merupakan faktor risiko underweight sedangkan indeks gingiva, indeks periodontal, dan indeks kebersihan mulut bukan faktor risiko underweight. Asupan energi (OR=6,3), protein $(O R=7,83)$, lemak $(O R=5,67)$, dan karbohidrat $(O R=7,5)$ yang kurang merupakan faktor risiko underweight $(p<0,01)$. Pendapatan kurang dari $R p$ 808.000,00 merupakan faktor risiko underweight $(O R=4,5$; $p<0,01)$. Analisis multivariat menunjukkan faktor risiko underweight yang bermakna adalah jumlah kehilangan gigi $\geq 21$ $(O R=8,76)$ dan 16-20 (OR=6,04) bila disertai dengan pendapatan kurang dari $R p$ 808.000,00 (OR=5,94) serta asupan lemak $(\mathrm{OR}=4,88)$ dan karbohidrat $(\mathrm{OR}=5,48)$ yang kurang. Pendapatan merupakan confounding factor risiko jumlah kehilangan gigi dan asupan protein terhadap underweight.

Simpulan: Faktor risiko underweight pada lansia yang bermakna adalah jumlah kehilangan gigi $\geq 16$, asupan lemak dan karbohidrat kurang, serta pendapatan kurang dari Rp 808.000,00.
\end{abstract}

KATA KUNCI: lansia, underweight, status kesehatan mulut, asupan makan

\footnotetext{
${ }^{1}$ Korespondensi: Program Studi Gizi Kesehatan, Fakultas Kedokteran Universitas Lampung, Jl. Prof. Dr. Sumantri Brojonegoro No. 1 Bandar Lampung, 35145, e-mail: riditie@yahoo.com

${ }^{2}$ Bagian Kedokteran Gigi Anak, Fakultas Kedokteran Gigi Universitas Gadjah Mada, Jl. Bulak Sumur, Yogyakarta 55281

${ }^{3}$ Bagian Penyakit Dalam, Rumah Sakit Umum Pusat Dr. Sardjito, Jl. Kesehatan No.1, Yogyakarta
} 


\section{PENDAHULUAN}

Persentase penduduk lansia Indonesia telah mencapai angka di atas 7\%, menunjukkan bahwa Indonesia merupakan kelompok negara berstruktur tua (ageing population), yang merupakan salah satu cerminan dari semakin panjangnya rata-rata usia penduduk Indonesia. Provinsi Daerah Istimewa Yogyakarta (DIY) memiliki jumlah lansia tertinggi yaitu sebesar $14,02 \%$ (1). Peningkatan umur harapan hidup di Indonesia dari 45 tahun di awal tahun 1950 menjadi 65 tahun sampai saat ini (2) dan DIY merupakan yang terbaik di Indonesia (3). Kota Yogyakarta merupakan salah satu kabupaten atau kota di Provinsi DIY, memiliki 14 kecamatan dengan 45 kelurahan atau desa yang semuanya termasuk dalam klasifikasi kota atau urban (4). Jumlah penduduk usia 45-64 tahun di Kota Yogyakarta saat ini mencapai 94.857 orang dan penduduk usia lebih dari atau sama dengan 65 tahun sebanyak 30.724 orang (3).

Salah satu perubahan fisiologis pada lansia adalah keadaan mulut berupa mulut kering karena berkurangnya saliva, gigi ompong atau gigi palsu yang tidak terpasang dengan baik yang dapat berakibat serius pada kualitas dan kuantitas asupan makanan. Beberapa kelompok makanan mungkin tidak dikonsumsi sama sekali (5). Perubahan fungsi pengunyahan karena kehilangan gigi akan mendorong lansia untuk mengubah asupan makanannya sebagai kompensasi kesulitan mengkonsumsi makanan tersebut. Lansia akan lebih memilih makanan yang lunak dan mudah dikunyah, diantaranya adalah makanan siap saji dengan rasa yang enak, tinggi kalori, dan tinggi lemak tetapi rendah kandungan zat gizi lainnya (6).

Berdasarkan data Riskesdas 2007, prevalensi nasional masalah gigi-mulut sebesar $23,4 \%$ dan kehilangan seluruh gigi asli sebesar $1,6 \%$ sedangkan pada kelompok umur 65 tahun ke atas mencapai 17,6\%. Prevalensi masalah gigi dan mulut serta kehilangan seluruh gigi asli, sedikit lebih tinggi pada perempuan $(1,8 \%)$ dibandingkan dengan laki-laki $(1,4 \%)$. Menurut tipe daerah, persentase penduduk yang mengalami kehilangan seluruh gigi asli sedikit lebih tinggi di pedesaan $(1,8 \%)$ dibandingkan dengan di perkotaan $(1,3 \%)(7)$.

Status kesehatan mulut antara lain diukur dengan indikator status kesehatan gigi dan indikator status periodontal (8). Indikator status kesehatan gigi menggunakan indeks decay missing filled-teeth (DMF-T) yang secara nasional sebesar 4,85 . Komponen yang terbesar adalah gigi dicabut/M-T sebesar 3,86. Pada kelompok umur 65 tahun atau lebih, indeks DMF-T sebesar 18,33 (D-T=1,16; M-T=16,99; F-T=0,14) (7). Penelitian yang dilakukan pada lansia di Paguyuban Among Yuswa Sleman diperoleh rata-rata indeks DMF-T pada lansia sebesar 12,49 (D-T=1,36; M-T=10,19) (9). Indikator status periodontal menurut WHO (1977) diukur berdasarkan adanya deposit lunak (debris), kalkulus, gingivitis, dan advanced periodontal involvement sedangkan menurut Depkes RI (1999) status periodontal diamati berdasarkan adanya kalkulus, periodontitis, dan gangguan periodontal lainnya (8).

Prevalensi malnutrisi pada lansia yang berada di rumah sakit, panti jompo maupun dalam program perawatan di rumah atau nursing homecare telah mencapai $15-60 \%$ $(10,11)$. Lansia yang umumnya menderita kekurangan gizi makro dan mikro akan memiliki respon sistem dan fungsi imun yang rendah (12). Penurunan asupan kalori total dan zat gizi esensial lainnya pada lansia dapat meningkatkan risiko penyakit dan infeksi. Infeksi dapat menyebabkan hipermetabolisme dan meningkatkan kebutuhan zat gizi, yang apabila tidak terpenuhi akan menurunkan berat badan dan status gizi lansia (13). Berdasarkan latar belakang tersebut, peneliti tertarik untuk mengetahui risiko status kesehatan mulut dan asupan makan terhadap kejadian underweight pada lansia di Kota Yogyakarta.

\section{BAHAN DAN METODE}

Jenis penelitian ini adalah penelitian observasional dengan rancangan case control yang dilakukan matching pada umur dan jenis kelamin. Kelompok kasus adalah lansia dengan status gizi kurang atau underweight dan kelompok kontrol adalah lansia dengan status gizi baik atau normoweight. Penelitian dilakukan di Kota Yogyakarta pada bulan November 2011 - Januari 2012. Populasi penelitian adalah seluruh lansia di Kota Yogyakarta. Berdasarkan hasil perhitungan sampel diperoleh jumlah sampel minimal yang harus dipenuhi adalah 210 orang (105 orang kelompok kasus dan 105 orang kelompok kontrol). Perhitungan besar sampel menggunakan rumus matched pairs case control (14) dengan nilai kepercayaan $95 \%$, kekuatan uji penelitian (power of the test) sebesar $80 \%$, proporsi asupan kalori inadekuat pada underweight sebesar 0,64 , dan odds ratio (OR) sebesar 2,5. Pengambilan sampel dilakukan dengan metode multistage random sampling.

Sampel penelitian diambil dari 5 kecamatan di Kota Yogyakarta yaitu Mantrijeron, Umbulharjo, Gondomanan, Wirobrajan, dan Jetis melalui kegiatan posyandu lansia yang ada di wilayah tersebut. Kriteria inklusi yang digunakan adalah berusia lebih dari atau sama dengan 60 tahun, masih bisa berkomunikasi dengan baik, terdaftar atau tercatat sebagai warga di wilayah penelitian. Kriteria eksklusinya adalah memakai gigi palsu, lansia yang mengalami penurunan daya ingat (gangguan penurunan kognitif dinilai dengan kuesioner mini mental state examination / MMSE), lansia yang menderita penyakit kronis yang membutuhkan diit khusus, dan ketidakmampuan merentangkan lengan dengan sempurna. Variabel bebas dalam penelitian ini adalah status kesehatan mulut dan asupan makan sedangkan 
variabel tergantungnya yaitu underweight. Selain itu, terdapat variabel yang berpotensi sebagai pengganggu yang turut diperhitungkan dalam penelitian ini yaitu pendidikan, pendapatan, dan status domisili.

Status kesehatan mulut meliputi indeks $\mathrm{M}$ atau jumlah kehilangan gigi, indeks gingiva, indeks periodontal, dan indeks kebersihan mulut (oral hygiene index / OHI). Indeks M diukur menggunakan indeks DMF-T (jumlah gigi yang karies (D), dicabut (M), dan ditambal dalam kondisi baik $(F)$ ). Skoring dari jumlah kehilangan gigi adalah skor 1 (kehilangan 1-5 gigi), skor 2 (kehilangan 6-10 gigi), skor 3 (kehilangan 11-15 gigi), skor 4 (kehilangan 16-20 gigi), dan skor 5 (kehilangan $\geq 21$ gigi).

Indeks gingiva menilai derajat inflamasi yang dilakukan pada 4 area gingiva di sisi gigi yaitu sisi fasial, mesial, distal, dan lingual. Kriteria penentuan skor yaitu 0 (gingiva normal); skor 1 (inflamasi ringan pada gingiva, yang ditandai perubahan warna, sedikit edema, pada palpasi tidak terjadi perdarahan); skor 2 (inflamasi gingiva sedang, warna merah, edema, berkilat, palpasi berdarah); dan skor 3 (inflamasi gingiva parah, warna merah, menyolok, edema, ulserasi, gingiva cenderung berdarah spontan). Skor dari ke-4 area sisi gigi tersebut dijumlahkan dan dibagi 4 untuk mendapatkan skor gigi yang diperiksa. Seluruh skor gigi kemudian dijumlahkan dan dibagi dengan jumlah gigi yang diperiksa sehingga didapatkan skor indeks gingiva. Setelah didapatkan skor indeks gingiva, kemudian ditentukan kriteria keparahan inflamasi gingiva secara klinis yaitu gingivitis ringan (skor=0,1-1,0), gingivitis sedang (skor=1,1-2,0), dan gingivitis berat $($ skor=2,1-3,0) (15).

Indeks periodontal (periodontal index/PI) mengukur keparahan inflamasi gingiva dan destruksi periodontal. Kriteria untuk indeks periodontal yaitu skor 0 (tidak ada inflamasi gingiva); skor 1 (gingivitis ringan, inflamasi ringan pada daerah gingiva bebas, tetapi perluasannya tidak sampai mengelilingi gigi); skor 2 (gingivitis, inflamasi meluas mengelilingi gigi tetapi perlekatan epitel belum mengalami kerusakan), skor 6 (gingivitis dengan pembentukan poket); dan skor 8 (destruksi lanjut disertai kehilangan fungsi pengunyahan, gigi goyang, drifting, pada perkusi tidak berbunyi nyaring) (15). Skor indeks periodontal individu diperoleh dari jumlah skor seluruh gigi dibagi dengan jumlah gigi yang diperiksa. Setelah didapatkan skor indeks periodontal maka dapat ditentukan kondisi klinisnya yaitu periodontal baik-periodontitis ringan (skor $\mathrm{PI}=0,0-1,9$ ), periodontitis sedang (skor $\mathrm{PI}=2,0-6,0$ ), dan periodontitis berat (skor $\mathrm{Pl}=6,1-8,0)$.

Indeks kebersihan mulut diukur melalui Simplified Oral Hygiene Index (OHIS) yang dilakukan dengan mengukur debris dan kalkulus, terdiri dari dua komponen yaitu indeks debris dan indeks kalkulus. Kriteria skor untuk indeks debris adalah skor 0 (tidak ada debris), skor 1 (debris lunak menutupi tidak lebih $1 / 3$ gigi), skor 2 (debis lunak menutupi lebih $1 / 3$ gigi), dan skor 3 (debris lunak menutupi lebih 2/3 gigi). Skor indeks kalkulus yaitu skor 0 (tidak ada kalkulus), skor 1 (kalkulus supragingiva menutupi tidak lebih 1/3 gigi), skor 2 (kalkulus supragingiva lebih dari 1/3 gigi atau ada flek-flek kalkulus subgingiva di sekeliling serviks gigi, atau keduanya), dan skor 3 (kalkulus supragingiva lebih 2/3 gigi atau ada kalkulus subgingiva disekeliling serviks gigi, atau keduanya). Skor indeks debris individu diperoleh dari jumlah skor berdasarkan kriteria indeks debris dibagi dengan jumlah gigi yang diperiksa, demikian pula dengan skor indeks kalkulus. Skor indeks debris dan kalkulus kemudian dijumlahkan dan didapatkan skor indeks kebersihan mulut $(\mathrm{OHI})$ yaitu baik (skor $\mathrm{OHI}=0,0-1,2)$, sedang (skor $\mathrm{OHI}=1,3-3,0$ ), dan buruk (skor $\mathrm{OHI}=3,1-6,0)(16,17)$.

Asupan makan diukur dengan semi quantitative food frequency questionnaire (SQFFQ) yaitu meliputi asupan energi, protein, lemak, dan karbohidrat yang dikonsumsi dalam waktu 3 bulan terakhir. Hasil estimasi asupan makan tersebut dibandingkan dengan nilai angka kecukupan gizi (AKG) rata-rata orang Indonesia yang disesuaikan menurut kelompok umur (2) dan dikelompokkan menjadi tiga, yaitu kurang (bila < 80\% AKG), cukup (80-110\% AKG), dan lebih (>110\% AKG) (9). Pada saat pengambilan data asupan makan, subjek diminta untuk menjelaskan seberapa sering mengkonsumsi setiap jenis makanan yang tercantum dalam kuesioner selama 3 bulan terakhir dengan kemungkinan jawaban yaitu berapa kali per hari, berapa kali per minggu, berapa kali per bulan, atau berapa kali per tiga bulan. Perhitungan asupan makan subjek dilakukan dengan cara mengalikan frekuensi konsumsi yang dilaporkan oleh subjek untuk setiap jenis makanan dengan besar porsi setiap kali makan (dalam gram) per hari, kemudian hasilnya dikalikan dengan kandungan zat gizi (energi, protein, lemak, karbohidrat) dalam setiap jenis makanan tersebut. Langkah terakhir adalah menjumlahkan kontribusi zat-zat gizi tersebut dari semua jenis makanan yang tercantum dalam kuesioner sehingga diperoleh rerata asupan makan subjek dalam 3 bulan terakhir. Pengambilan data asupan makan menggunakan bantuan food model.

Data status gizi diperoleh dengan menentukan body mass armspan (BMA) yaitu dengan cara membandingkan berat badan $(\mathrm{kg})$ dan rentang lengan $\left(\mathrm{m}^{2}\right)$ kemudian dibedakan menjadi 3 kategori, yaitu status gizi lebih (perempuan $>22,8$; laki-laki $>25,1$ ), status gizi baik (perempuan 18,7-22,8; laki-laki 20,1-25), dan status gizi kurang atau underweight (perempuan $<18,7$; laki-laki $<20,1)(18)$. Berat badan diukur menggunakan timbangan injak dengan ketelitian $0,1 \mathrm{~kg}$ sedangkan rentang lengan diukur menggunakan pita meteran dengan ketelitian 0,1 $\mathrm{cm}$. Data umur, jenis kelamin, pendidikan, pendapatan, dan status domisili diperoleh melalui kuesioner yang ditanyakan kepada subjek. Pendidikan dibagi menjadi 3 kategori, yaitu pendidikan rendah (paket $A, S D$ ), menengah (SMP, SMA), dan tinggi (diploma, perguruan tinggi). 
Tabel 1. Karakteristik subjek penelitian pada kelompok underweight dan normoweight

\begin{tabular}{|c|c|c|c|c|c|c|c|c|}
\hline \multirow{3}{*}{ Variabel } & \multicolumn{4}{|c|}{ Status gizi } & & & \multirow{3}{*}{$x^{2}$} & \multirow{3}{*}{$\mathbf{p}$} \\
\hline & \multicolumn{2}{|c|}{$\begin{array}{l}\text { Underweight } \\
\text { (kasus) }\end{array}$} & \multicolumn{2}{|c|}{$\begin{array}{l}\text { Normoweight } \\
\text { (kontrol) }\end{array}$} & \multicolumn{2}{|c|}{ Total } & & \\
\hline & $\mathbf{n}$ & $\%$ & $\mathbf{n}$ & $\%$ & $\mathbf{n}$ & $\%$ & & \\
\hline \multicolumn{9}{|l|}{ Umur (tahun) ${ }^{a}$} \\
\hline $60-64$ & 39 & 37,14 & 39 & 37,14 & 78 & 37,14 & & \\
\hline $65-69$ & 22 & 20,95 & 22 & 20,95 & 44 & 20,95 & & \\
\hline $70-74$ & 20 & 19,05 & 20 & 19,05 & 40 & 19,05 & & \\
\hline $75-79$ & 15 & 14,29 & 15 & 14,29 & 30 & 14,29 & & \\
\hline $80-84$ & 8 & 7,62 & 8 & 7,62 & 16 & 7,62 & & \\
\hline $85-89$ & 1 & 0,95 & 1 & 0,95 & 2 & 0,95 & & \\
\hline \multicolumn{9}{|l|}{ Jenis kelamin ${ }^{a}$} \\
\hline Laki-laki & 28 & 26,67 & 28 & 26,67 & 56 & 26,67 & & \\
\hline Perempuan & 77 & 73,33 & 77 & 73,33 & 154 & 73,33 & & \\
\hline \multicolumn{9}{|l|}{ Pendidikan terakhir ${ }^{b}$} \\
\hline Rendah & 50 & 47,62 & 43 & 40,95 & 93 & 44,29 & \multirow{3}{*}{2,80} & \multirow{3}{*}{0,25} \\
\hline Menengah & 44 & 41,9 & 45 & 42,86 & 89 & 42,38 & & \\
\hline Tinggi & 11 & 10,48 & 17 & 16,19 & 28 & 13,33 & & \\
\hline \multicolumn{9}{|l|}{ Pendapatanc } \\
\hline Rendah (< Rp 808.000,-) & 76 & 72,38 & 48 & 45,71 & 124 & 59,05 & \multirow[t]{2}{*}{17,82} & \multirow[t]{2}{*}{0,00} \\
\hline Tinggi ( $\geq$ Rp 808.000,-) & 29 & 27,62 & 57 & 54,29 & 86 & 40,95 & & \\
\hline \multicolumn{9}{|l|}{ Status domisilic } \\
\hline Tinggal bersama keluarga & 99 & 94,29 & 103 & 98,10 & 202 & 96,19 & \multirow[t]{2}{*}{2,67} & \multirow[t]{2}{*}{0,10} \\
\hline Tinggal seorang diri & 6 & 5,71 & 2 & 1,90 & 8 & 3,81 & & \\
\hline
\end{tabular}

Keterangan : ${ }^{\mathrm{a}}=$ variabel matching kelompok kasus dan kelompok kontrol;

${ }^{b}=$ uji $X^{2}$ Stuart Maxwell; ${ }^{c}=$ uji $X^{2}$ Mc. Nemar; ${ }^{*}=$ bermakna $(p<0,05)$

Pendapatan dibagi menjadi 2 kategori berdasarkan upah minimum provinsi (UMP) tahun 2011, yaitu rendah $(<\mathrm{Rp}$ $808.000,00)$ dan tinggi $(\geq \operatorname{Rp} 808.000,00)$. Status domisili dibedakan menjadi 2 kategori, yaitu tinggal seorang diri dan tinggal bersama keluarga.

Pengumpulan data dilakukan oleh peneliti dengan bantuan 6 orang enumerator yang telah diberikan pengarahan dan pelatihan sebelumnya. Data tersebut selanjutnya diuji secara statistik dengan derajat kemaknaan 95\% $(p<0,05)$ menggunakan uji $X^{2}$ Mc.Nemar, $X^{2}$ Stuart Maxwell, dan conditional logistic regression. Penelitian ini dilaksanakan setelah mendapatkan surat ethical clearance penelitian dari Komite Etika Fakultas Kedokteran Universitas Gadjah Mada.

\section{HASIL}

Subjek penelitian berjumlah 210 orang yang tinggal di Kecamatan Mantrijeron, Umbulharjo, Gondomanan, Wirobrajan, dan Jetis. Sebagian besar subjek berusia 60-64 tahun $(37,14 \%)$ dan berjenis kelamin perempuan (73,33\%). Pendidikan rendah (47,62\%) terbanyak terdapat pada kelompok kasus sedangkan pendidikan menengah $(42,86 \%)$ pada kelompok kontrol. Sebagian besar $(72,38 \%)$ tingkat pendapatan pada kelompok kasus tergolong rendah, sebaliknya pada kelompok kontrol sebagian besar tingkat pendapatan tergolong tinggi $(54,29 \%)$. Secara statistik ada perbedaan bermakna tingkat pendapatan antara kelompok kasus dan kontrol. Sebagian besar subjek pada kedua kelompok tinggal bersama keluarga yaitu sebesar 94,29\% (kelompok kasus) dan 98,10\% (kelompok kontrol) (Tabel 1).

Rata-rata jumlah kehilangan gigi pada kelompok kasus adalah 14 gigi dan pada kelompok kontrol adalah 11 gigi. Dengan demikian, dapat diketahui bahwa kelompok kasus rata-rata memiliki 18 gigi dan kelompok kontrol rata-rata memiliki 21 gigi yang digunakan untuk fungsi pengunyahan. Rerata skor indeks gingival, indeks periodontal, dan skor indeks kebersihan mulut tidak berbeda pada kedua kelompok. Reata asupan makan pada kelompok kasus lebih rendah dibandingkan kelompok kontrol yaitu rerata asupan energi 369,94 kkal lebih rendah, rerata asupan protein 19,66 gram lebih rendah, rerata asupan lemak 14,5 gram lebih rendah, dan rerata asupan karbohidrat 57,11 gram lebih rendah pada kelompok kasus dibandingkan kelompok kontrol (Tabel 2).

Pada kelompok kasus, jumlah terbanyak untuk kehilangan gigi atau indeks $\mathrm{M}$ adalah kehilangan lebih dari atau sama dengan 21 gigi atau skor $5(23,81 \%)$, gingivitis sedang $(52,38 \%)$, periodontitis sedang $(47,62)$, dan indeks kebersihan mulut sedang $(58,10 \%)$. Sementara itu, sebagian besar subjek pada kelompok kontrol mengalami kehilangan gigi 6-10 atau skor $2(37,14 \%)$, gingivitis sedang $(58,10 \%)$, periodontal baik-periodontitis ringan $(47,62 \%)$, dan indeks kebersihan mulut sedang $(64,76 \%)$. Berdasarkan hasil analisis, jumlah kehilangan gigi merupakan faktor risiko underweight. Pada jumlah kehilangan gigi lebih dari atau sama dengan 21 gigi (skor 5) didapatkan nilai OR=3,67 (95\%Cl: 1,18-11,35), 
Tabel 2. Deskripsi status kesehatan mulut dan asupan makan subjek penelitian

\begin{tabular}{|c|c|c|c|c|c|c|c|c|}
\hline \multirow[t]{2}{*}{ Variabel } & \multicolumn{4}{|c|}{$\begin{array}{l}\text { Underweight } \\
\text { (kasus) }\end{array}$} & \multicolumn{4}{|c|}{$\begin{array}{l}\text { Normoweight } \\
\text { (kontrol) }\end{array}$} \\
\hline & Rerata & SD & Min & Maks & Rerata & SD & Min & Maks \\
\hline Jumlah kehilangan gigi & 13,68 & 8,36 & 1 & 30 & 11,15 & 7,58 & 2 & 31 \\
\hline Status gingiva & 1,36 & 0,60 & 0,1 & 2,67 & 1,31 & 0,47 & 0,29 & 2,33 \\
\hline Status periodontal & 2,68 & 1,91 & 0 & 7 & 2,46 & 1,63 & 0 & 6,67 \\
\hline Status kebersihan mulut & 2,52 & 1,14 & 0 & 5,67 & 2,34 & 0,97 & 0,44 & 6 \\
\hline Asupan energi & 1156,48 & 294,67 & 588,4 & 2067,9 & 1526,42 & 367,60 & 786,2 & 3284,5 \\
\hline Asupan protein & 43,80 & 13,44 & 18,3 & 83,5 & 63,46 & 20,09 & 26,9 & 139,9 \\
\hline Asupan lemak & 32,38 & 10,77 & 5,8 & 59,4 & 46,88 & 15,27 & 5,3 & 100,6 \\
\hline Asupan karbohidrat & 171,94 & 49,82 & 74,3 & 324,5 & 229,05 & 55,87 & 99,1 & 477,4 \\
\hline
\end{tabular}

Keterangan: Min = nilai minimun; Maks = nilai maksimum; SD = standar deviasi

Tabel 3. Analisis bivariat status kesehatan mulut, asupan makan, dan faktor sosioekonomi terhadap status gizi underweight

\begin{tabular}{|c|c|c|c|c|c|c|}
\hline \multirow{2}{*}{ Variabel } & \multicolumn{2}{|c|}{$\begin{array}{c}\text { Underweight } \\
\text { (kasus) }\end{array}$} & \multicolumn{2}{|c|}{$\begin{array}{l}\text { Normoweight } \\
\text { (kontrol) }\end{array}$} & \multirow[t]{2}{*}{ OR } & \multirow[t]{2}{*}{$95 \% \mathrm{Cl}$} \\
\hline & $n$ & $\%$ & $\mathrm{n}$ & $\%$ & & \\
\hline \multicolumn{7}{|l|}{ Jumlah kehilangan gigi } \\
\hline Skor 5 & 25 & 23,81 & 15 & 14,29 & 3,67 & $1,18-11,35$ \\
\hline Skor 4 & 18 & 17,14 & 10 & 9,52 & 3,53 & $1,07-11,64$ \\
\hline Skor 3 & 22 & 20,95 & 17 & 16,19 & 1,88 & $0,76-4,64$ \\
\hline Skor 2 & 21 & 20,00 & 39 & 37,14 & 0,80 & $0,36-1,79$ \\
\hline Skor 1 & 19 & 18,10 & 24 & 22,86 & & \\
\hline \multicolumn{7}{|l|}{ Indeks gingiva } \\
\hline Gingivitis berat & 15 & 14,29 & 10 & 9,52 & 1,57 & $0,57-4,30$ \\
\hline Gingivitis sedang & 55 & 52,38 & 61 & 58,10 & 0,87 & $0,47-1,61$ \\
\hline Gingivitis ringan & 35 & 33,33 & 34 & 32,38 & & \\
\hline \multicolumn{7}{|l|}{ Indeks periodontal } \\
\hline Periodontitis berat & 11 & 10,48 & 8 & 7,62 & 1,58 & $0,55-4,53$ \\
\hline Periodontitis sedang & 50 & 47,62 & 47 & 44,76 & 1,18 & $0,67-2,06$ \\
\hline Periodontal baik-periodontitis ringan & 44 & 41,90 & 50 & 47,62 & & \\
\hline \multicolumn{7}{|l|}{ Indeks kebersihan mulut } \\
\hline Buruk & 33 & 31,43 & 22 & 20,95 & 1,93 & $0,78-4,75$ \\
\hline Sedang & 61 & 58,10 & 68 & 64,76 & 1,14 & $0,51-2,58$ \\
\hline Baik & 11 & 10,48 & 15 & 14,29 & & \\
\hline \multicolumn{7}{|l|}{ Asupan energi } \\
\hline Kurang & 83 & 79,05 & 30 & 28,57 & 6,3 & $3,23-12,28$ \\
\hline Cukup-lebih & 22 & 20,95 & 75 & 71,43 & & \\
\hline \multicolumn{7}{|l|}{ Asupan protein } \\
\hline Kurang & 51 & 48,57 & 10 & 9,52 & 7,83 & $3,34-22,42$ \\
\hline Cukup-lebih & 54 & 51,43 & 95 & 90,48 & & \\
\hline \multicolumn{7}{|l|}{ Asupan lemak } \\
\hline Kurang & 77 & 73,33 & 35 & 33,33 & 5,67 & $2,76-13,09$ \\
\hline Cukup-lebih & 28 & 26,67 & 70 & 66,67 & & \\
\hline \multicolumn{7}{|l|}{ Asupan karbohidrat } \\
\hline Kurang & 88 & 83,81 & 36 & 34,28 & 7,5 & $3,57-18,16$ \\
\hline Cukup-lebih & 17 & 16,19 & 69 & 65,72 & & \\
\hline \multicolumn{7}{|l|}{ Pendidikan } \\
\hline Rendah & 50 & 47,62 & 43 & 40,95 & 2,50 & $0,83-7,52$ \\
\hline Menengah & 44 & 41,90 & 45 & 42,86 & 1,84 & $0,68-4,99$ \\
\hline Tinggi & 11 & 10,48 & 17 & 16,19 & & \\
\hline \multicolumn{7}{|l|}{ Pendapatan } \\
\hline Rendah & 76 & 72,38 & 48 & 45,71 & 4,5 & $2,06-11,20$ \\
\hline Tinggi & 29 & 27,62 & 57 & 54,29 & & \\
\hline \multicolumn{7}{|l|}{ Status domisili } \\
\hline Tinggal seorang diri & 6 & 5,71 & 2 & 1,90 & 5 & $0,58-42,79$ \\
\hline Tinggal bersama keluarga & 99 & 94,29 & 103 & 98,10 & & \\
\hline
\end{tabular}


artinya kejadian underweight pada lansia dengan jumlah kehilangan gigi lebih dari atau sama dengan 21 gigi memiliki risiko 3,67 kali lebih tinggi dibandingkan lansia dengan jumlah kehilangan gigi 1-5 buah (skor 1). Jumlah kehilangan gigi 16-20 buah (skor 4) didapatkan nilai $\mathrm{OR}=3,53(95 \% \mathrm{Cl}: 1,07-11,64)$ yang berarti lansia dengan jumlah kehilangan gigi 16-20 buah mempunyai risiko 3,53 kali untuk berstatus gizi underweight dibandingkan lansia dengan jumlah kehilangan gigi 1-5 buah. Selain itu, hasil analisis juga menunjukkan bahwa indeks gingiva, indeks periodontal, dan indeks kebersihan mulut bukan merupakan faktor risiko kejadian underweight pada lansia (Tabel 3).

Pada kelompok kasus, jumlah terbesar adalah subjek dengan asupan energi kurang $(79,05 \%)$, asupan protein cukup-lebih $(51,43 \%)$, asupan lemak kurang $(73,33 \%)$, dan asupan karbohidrat kurang (83,81\%). Sementara itu, sebagian besar subjek pada kelompok kontrol memiliki asupan energi, protein, lemak, dan karbohidrat yang tergolong cukup-lebih. Uji $\mathrm{X}^{2}$ McNemar menunjukkan bahwa asupan energi merupakan faktor risiko underweight pada lansia dengan $\mathrm{OR}=6,3(95 \% \mathrm{Cl}: 3,23-12,28)$, artinya lansia dengan asupan energi kurang memiliki risiko 6,3 kali lebih tinggi untuk berstatus gizi underweight dibandingkan dengan lansia dengan asupan energi cukup-lebih. Demikian juga dengan hasil analisis pada asupan protein, lemak, dan karbohidrat yang kurang menunjukkan risiko lebih tinggi untuk berstatus gizi underweight $(\mathrm{OR}=7,83$; $\mathrm{OR}=5,67 ; \mathrm{OR}=7,5$ ) dibandingkan lansia dengan asupan protein, lemak, dan karbohidrat cukup-lebih (Tabel 3).

Hasil analisis juga menunjukkan bahwa pendidikan dan status domisili bukan merupakan faktor risiko underweight pada lansia. Sebaliknya, pendapatan rendah (< Rp 808.000,00) merupakan faktor risiko underweight pada lansia dengan $\mathrm{OR}=4,5(95 \% \mathrm{Cl}: 2,06-11,20)$, artinya lansia dengan pendapatan kurang dari Rp 808.000,00 mempunyai risiko 4,5 kali lebih tinggi untuk berstatus gizi underweight dibandingkan lansia dengan pendapatan lebih dari Rp 808.000,00 (Tabel 3).

Analisis multivariat dilakukan dengan uji regresi logistik ganda menggunakan pemodelan dengan membandingkan nilai OR status kesehatan mulut, asupan makan, dan faktor sosioekonomi secara bersama-sama (Tabel 4). Pada analisis status kesehatan mulut, yang paling bermakna adalah jumlah kehilangan gigi (Model 1 dan 3) dan pendapatan merupakan efek modifikasi (Model 5) pada risiko jumlah kehilangan gigi terhadap underweight setelah dilakukan analisa stratifikasi. Selain itu, terdapat perbedaan OR yang besar yaitu 14,89 pada strata pendapatan rendah dan 1,19 pada strata pendapatan tinggi (pendapatan rendah merupakan interaksi atau efek modifikasi). Variabel asupan makan yang paling bermakna adalah asupan lemak dan karbohidrat (Model 2 dan Model 4).
Tabel 4. Analisis multivariat

\begin{tabular}{|c|c|c|c|c|}
\hline & Model dan variabel & OR & $\mathbf{p}$ & $\mathbf{R}^{2}$ \\
\hline \multirow[t]{14}{*}{ Model 1} & Jumlah kehilangan gigi & & & \multirow{14}{*}{0,126} \\
\hline & Skor 5 & 4,75 & $0,016^{*}$ & \\
\hline & Skor 4 & 4,21 & $0,028^{*}$ & \\
\hline & Skor 3 & 2,14 & 0,117 & \\
\hline & Skor 2 & 0,94 & 0,895 & \\
\hline & \multicolumn{3}{|l|}{ Indeks gingival } & \\
\hline & Gingivitis berat & 1,04 & 0,956 & \\
\hline & Gingivitis sedang & 0,61 & 0,240 & \\
\hline & \multicolumn{3}{|l|}{ Indeks periodontal } & \\
\hline & Periodontitis berat & 0,65 & 0,579 & \\
\hline & Periodontitis sedang & 0,93 & 0,847 & \\
\hline & Indeks kebersihan mulut & & & \\
\hline & Buruk & 2,09 & 0,181 & \\
\hline & Sedang & 1,32 & 0,550 & \\
\hline \multirow[t]{4}{*}{ Model 2} & Asupan energi kurang & 1,93 & 0,164 & \multirow{4}{*}{0,505} \\
\hline & Asupan protein kurang & 1,97 & 0,209 & \\
\hline & Asupan lemak kurang & 4,08 & $0,012^{*}$ & \\
\hline & Asupan karbohidrat kurang & 5,78 & $0,000^{*}$ & \\
\hline \multirow[t]{19}{*}{ Model 3} & Jumlah kehilangan gigi & & & \multirow{19}{*}{0,289} \\
\hline & Skor 5 & 10,99 & $0,003^{*}$ & \\
\hline & Skor 4 & 8,25 & $0,006^{*}$ & \\
\hline & Skor 3 & 4,14 & $0,026^{*}$ & \\
\hline & Skor 2 & 1,39 & 0,525 & \\
\hline & \multicolumn{3}{|l|}{ Indeks gingival } & \\
\hline & Gingivitis berat & 0,63 & 0,556 & \\
\hline & Gingivitis sedang & 0,62 & 0,822 & \\
\hline & \multicolumn{3}{|l|}{ Indeks periodontal } & \\
\hline & Periodontitis berat & 0,63 & 0,579 & \\
\hline & Periodontitis sedang & 0,91 & 0,822 & \\
\hline & \multicolumn{3}{|l|}{ Indeks kebersihan mulut } & \\
\hline & Buruk & 2,92 & 0,113 & \\
\hline & Sedang & 2,27 & 0,161 & \\
\hline & \multicolumn{3}{|l|}{ Pendidikan } & \\
\hline & Rendah & 0,32 & 0,175 & \\
\hline & Menengah & 0,61 & 0,461 & \\
\hline & Pendapatan rendah & 9,13 & $0,000^{*}$ & \\
\hline & $\begin{array}{l}\text { Status domisili tinggal seorang } \\
\text { diri }\end{array}$ & 3,53 & 0,309 & \\
\hline \multirow[t]{9}{*}{ Model 4} & Asupan energi kurang & 1,88 & 0,214 & \multirow{9}{*}{0,543} \\
\hline & Asupan protein kurang & 1,54 & 0,471 & \\
\hline & Asupan lemak kurang & 4,88 & $0,010^{*}$ & \\
\hline & Asupan karbohidrat kurang & 5,48 & $0,002^{*}$ & \\
\hline & \multicolumn{3}{|l|}{ Pendidikan } & \\
\hline & Dasar & 1,57 & 0,616 & \\
\hline & Menengah & 1,68 & 0,490 & \\
\hline & Pendapatan rendah & 2,19 & 0,181 & \\
\hline & $\begin{array}{l}\text { Status domisili tinggal seorang } \\
\text { diri }\end{array}$ & 5,69 & 0,189 & \\
\hline Model 5 & Jumlah kehilangan gigi & & & \multirow{6}{*}{0,245} \\
\hline & Skor 5 & 5,77 & $0,007^{*}$ & \\
\hline & Skor 4 & 4,81 & $0,016^{*}$ & \\
\hline & Skor 3 & 2,46 & 0,093 & \\
\hline & Skor 2 & 0,94 & 0,895 & \\
\hline & Pendapatan rendah & 5,60 & $0,000^{*}$ & \\
\hline Model 6 & Asupan energi kurang & 5,7 & $0,000^{*}$ & 0358 \\
\hline & Pendapatan rendah & 3,64 & $0,005^{*}$ & 0,358 \\
\hline Model 7 & Asupan protein kurang & 6,38 & $0,000^{*}$ & \\
\hline & Pendapatan rendah & 3,16 & $0,008^{*}$ & 0,304 \\
\hline Model 8 & Asupan lemak kurang & 5,51 & $0,000^{*}$ & \\
\hline & Pendapatan rendah & 4,32 & $0,001^{*}$ & 0,318 \\
\hline Model 9 & Asupan karbohidrat kurang & 6,37 & $0,000^{*}$ & \\
\hline & Pendapatan rendah & 3,09 & $0,013^{*}$ & $0,35 /$ \\
\hline
\end{tabular}

Keterangan: ${ }^{*}=$ signifikan $(p<0,05)$ 
Pada analisis multivariat juga dilakukan adjustment untuk mengetahui hubungan antara variabel independen terhadap variabel dependen dengan mengontrol variabel faktor sosioekonomi yang berpotensi sebagai variabel pengganggu (Model 5-9) dengan beda taksiran OR crude dan adjustment lebih dari $20 \%$. Hasil analisis menunjukkan bahwa pendapatan merupakan variabel pengganggu (confounding factor) risiko jumlah kehilangan gigi terhadap underweight $(\triangle \mathrm{OR}=36,39 \%)$ dan risiko asupan protein terhadap underweight $(\triangle \mathrm{OR}=22,72 \%)$.

\section{BAHASAN}

Hasil penelitian ini menunjukkan bahwa subjek pada kelompok kasus rata-rata memiliki 18 gigi dan pada kelompok kontrol memiliki 21 gigi yang dipergunakan untuk fungsi pengunyahan. Fungsi pengunyahan yang cukup atau sedikit berkurang yang diharapkan bagi lansia adalah dengan adanya minimal 20 gigi asli (19). Kelompok kasus rata-rata memiliki 18 gigi sehingga menunjukkan bahwa telah terjadi penurunan fungsi pengunyahan yang berakibat pada asupan makan kurang dan status gizi underweight. Sementara itu, kelompok kontrol memiliki 21 gigi sehingga fungsi pengunyahan masih cukup ataupun sedikit berkurang yang berdampak pada asupan makan cukup dan status gizi baik.

Penurunan fungsi fisiologis rongga mulut pada lansia yaitu banyaknya gigi tanggal dan kerusakan gingiva karena proses degenerasi, akan mempengaruhi proses mekanisme makanan terutama proses pengunyahan. Lansia akan kesulitan untuk mengkonsumsi makanan berkonsistensi keras. Penurunan sekresi saliva juga berpengaruh pada proses pencernaan makanan di rongga mulut karena enzim ptialin menurun. Selain itu, kerusakan gigi dan gingiva menimbulkan ketidaknyaman dan rasa sakit saat mengunyah makanan sehingga menurunkan selera makan lansia (2).

Analisis bivariat menunjukkan bahwa jumlah kehilangan gigi lebih dari atau sama dengan 16 merupakan faktor risiko underweight pada lansia. Sedikitnya jumlah gigi yang dimiliki subjek pada kelompok kasus menyebabkan subjek mengurangi bahkan tidak mengkonsumsi makanan dengan tekstur keras dan cenderung mengkonsumsi makanan lunak yang mudah dikunyah. Berdasarkan hasil wawancara diketahui bahwa lansia underweight dengan jumlah gigi sedikit mulai mengubah pola asupan makan dengan lebih banyak mengkonsumsi makanan bertekstur lunak seperti bubur nasi, mie instan, tahu-tempe rebus, dan umbi-umbian rebus. Selain itu, diketahui bahwa cara pengolahan makanan tidak banyak berubah, makanan diolah seperti biasa, tidak dicincang atau dihaluskan atau diblender sehingga konsumsi makanan lansia underweight pun sedikit karena makanan yang tersedia sulit untuk dikunyah. Sedikitnya asupan energi dan zat gizi lainnya menyebabkan lansia berada pada status gizi underweight.
Hasil analisis multivariat menunjukkan jumlah kehilangan gigi merupakan faktor risiko yang bermakna terhadap underweight pada lansia dan setelah dianalisis bersama-sama dengan faktor sosioekonomi, pendapatan merupakan variabel yang berperan pada jumlah kehilangan gigi terhadap underweight (efek modifikasi/interaksi). Artinya, lansia dengan kehilangan gigi lebih dari atau sama dengan 16 memiliki risiko yang lebih besar berstatus gizi underweight bila disertai pendapatan kurang dari Rp $808.000,00$. Hal ini berkaitan dengan perawatan kesehatan gigi dan mulut, lansia dengan pendapatan rendah, tidak memiliki cukup biaya untuk mendapatkan perawatan gigi dan mulut yang memadai termasuk merawat gigi rusak dan mengganti gigi yang tanggal (20). Pendapatan juga merupakan variabel pengganggu (confounding factor) pada risiko jumlah kehilangan gigi terhadap underweight.

Penyebab utama kehilangan gigi geligi untuk lansia di Indonesia adalah karies dan penyakit periodontal (21). Penyakit periodontal merupakan salah satu penyakit yang meluas di masyarakat sehingga dianggap sebagai sesuatu yang tidak dapat dihindari. Penyakit periodontal yang paling sering dijumpai adalah gingivitis dan periodontitis. Seperti karies gigi, penyakit periodontal juga lambat perkembangannya dan apabila tidak dirawat dapat menyebabkan kehilangan gigi (22).

Pada penelitian ini, rata-rata nilai indeks gingiva kelompok kasus $(1,36)$ tidak jauh berbeda dengan kelompok kontrol $(1,31)$. Hal ini menunjukkan adanya inflamasi gingiva sedang yang dialami sebagian besar lansia. Berdasarkan hasil analisis bivariat, diketahui bahwa gingivitis berat ataupun sedang bukan merupakan faktor risiko underweight pada lansia. Pengaruh gingivitis terhadap underweight merupakan proses yang tidak langsung, gingivitis berat yang tidak dirawat dan dibiarkan dalam jangka waktu lama bisa berkembang menjadi periodontitis dan menyebabkan gigi tanggal. Gingivitis tidak selalu menimbulkan rasa sakit sehingga tidak menyebabkan gangguan dalam proses pengunyahan dan menelan makanan. Sementara itu, rerata indeks periodontal kelompok kasus $(2,68)$ dan kelompok kontrol $(2,46)$ tidak jauh berbeda yaitu menunjukkan adanya inflamasi yang mengelilingi gigi dan perlekatan epitel sedikit mengalami destruksi tetapi belum ada hambatan pengunyahan. Berdasarkan analisis bivariat diperoleh bahwa periodontitis berat ataupun sedang bukan merupakan faktor risiko underweight pada lansia. Pengaruh periodontitis terhadap underweight pada lansia merupakan proses yang tidak langsung. Adanya deposit debris dan kalkulus secara bermakna berhubungan dengan kejadian tanggalnya gigi (23). Sisa makanan dan debris yang tidak dibersihkan merupakan tempat pertumbuhan bakteri sehingga bisa menimbulkan periodontitis (24).

Hasil penelitian ini juga menunjukkan rerata indeks kebersihan mulut pada kedua kelompok tidak jauh berbeda, 
yaitu 2,52 pada kelompok kasus dan 2,34 pada kelompok kontrol, yang menunjukkan adanya debris dan kalkulus di $1 / 3$ sampai $2 / 3$ permukaan gigi. Secara umum, indeks kebersihan mulut kelompok kasus dan kelompok kontrol adalah sedang. Analisis bivariat menunjukkan bahwa indeks kebersihan mulut yang buruk bukan merupakan faktor risiko underweight pada lansia.

Selain status kesehatan mulut, asupan makan merupakan faktor yang berpengaruh langsung secara linier dalam menentukan status gizi seseorang. Asupan makan (energi, protein, lemak, dan karbohidrat) berhubungan dengan status gizi (25). Pada lansia, energi dibutuhkan untuk menjaga sel-sel tubuh agar tetap berfungsi dengan baik walaupun fungsinya tidak sebaik saat masih muda (2). Hasil penelitian ini membuktikan bahwa rerata asupan energi kelompok kasus 369,94 kkal lebih rendah daripada kelompok kontrol. Hal ini menunjukkan perbedaan yang cukup besar, asupan energi rata-rata kelompok kasus lebih rendah hampir dari setengah kecukupan energi lansia. Analisis bivariat juga menunjukkan asupan makan (energi, protein, lemak, dan karbohidrat) yang kurang merupakan faktor risiko underweight pada lansia. Nilai OR untuk energi, protein, lemak, dan karbohidrat menunjukkan angka lebih dari 1 yang menunjukkan adanya hubungan yang positif antara asupan makan yang kurang dengan kejadian underweight. Hasil penelitian ini kemungkinan dipengaruhi oleh sedikitnya jumlah gigi yang dimiliki oleh subjek sehingga menimbulkan gangguan pengunyahan makanan. Hal tersebut menyebabkan terjadinya perubahan kualitas dan kuantitas asupan makan yang pada akhirnya berdampak pada berat badan dan status gizi. Analisis multivariat menunjukkan bahwa asupan makan yang paling bermakna sebagai faktor risiko underweight adalah asupan lemak dan karbohidrat yang kurang.

Lansia underweight memiliki rerata asupan protein 19,66 gram lebih rendah dibandingkan lansia berstatus gizi normal, selisih tersebut lebih dari $30 \%$ angka kecukupan. Asupan protein yang kurang menyebabkan penyusutan massa otot sehingga terjadi penurunan berat badan yang pada akhirnya menjadi underweight. Sebagian besar asupan protein subjek pada kelompok kasus diperoleh dari tahu, tempe, telur, dan susu. Hanya sebagian kecil asupan protein yang terpenuhi dari ikan, ayam, dan daging sapi. Berbeda dengan subjek pada kelompok kontrol yang sebagian besar asupan proteinnya tergolong cukup-lebih. Berdasarkan hasil wawancara SQFFQ, sumber protein yang dikonsumsi banyak berasal dari susu, daging dan olahannya, telur, unggas serta ikan tawar dan laut. Subjek juga menyatakan bahwa sedang berusaha mengurangi asupan sumber karbohidrat dan lemak untuk menjaga kesehatan tetapi meningkatkan asupan sumber protein dan serat. Hal ini kemungkinan disebabkan oleh banyaknya jumlah gigi yang dimiliki subjek pada kelompok kontrol sehingga tidak ada kesulitan atau gangguan fungsi pengunyahan dalam mengkonsumsi protein dan serat. Selain itu, hasil penelitian juga menunjukkan bahwa pendapatan merupakan confounding factor pada risiko asupan protein terhadap underweight. Pendapatan mempengaruhi daya beli seseorang, subjek pada kelompok kontrol memiliki pendapatan yang lebih besar daripada kelompok kasus sehingga subjek bisa membeli sumber protein lebih banyak dan beraneka ragam.

Penurunan asupan lemak jauh di bawah kebutuhan akan berdampak pada berat badan dan status gizi lansia. Berdasarkan hasil wawancara dengan menggunakan SQFFQ diketahui bahwa sebagian besar asupan lemak diperoleh dari penggunaan minyak goreng dan santan dalam pengolahan makanan, yang secara disadari dikurangi konsumsinya oleh subjek, baik pada kelompok kasus maupun kontrol. Asupan lemak yang kurang menyebabkan jumlah energi yang diperoleh juga lebih sedikit karena lemak memberikan kontribusi sebesar 9 kilokalori per gramnya. Sementara itu, sumber karbohidrat subjek diperoleh dari nasi, mie, bihun, roti, jagung, umbiumbian, dan minuman manis. Sebagian lansia underweight secara sadar mengurangi jumlah makanan sumber karbohidrat dengan alasan untuk menjaga kesehatan dan tanpa sadar mereka berada pada status gizi underweight. Namun, sebagian subjek lainnya memang mengkonsumsi sumber karbohidrat dengan jumlah kurang dari kebutuhan disebabkan faktor ekonomi.

Hasil penelitian ini menunjukkan bahwa pendapatan kurang dari $\mathrm{Rp} 808.000,00$ merupakan faktor risiko underweight pada lansia. Pendapatan secara bermakna memiliki hubungan linier dengan status gizi, yaitu pendapatan di atas UMP berhubungan dengan status gizi baik. Pendapatan rumah tangga yang meningkat akan diikuti dengan perbaikan kualitas makanan (9). Tingkat pendapatan juga berhubungan dengan cara memelihara diri dan kesempatan mendapatkan pelayanan kesehatan (26). Pendapatan yang rendah menyebabkan kesulitan dalam memperoleh makanan dan memperbaiki atau mengganti gigi yang rusak, yang pada akhirnya akan menyebabkan lansia berada pada status gizi kurang.

\section{SIMPULAN DAN SARAN}

Kehilangan gigi lebih dari atau sama dengan 16 gigi, asupan makan (energi, protein, lemak, dan karbohidrat) yang kurang, dan pendapatan kurang dari Rp 808.000,00 merupakan faktor risiko underweight pada lansia. Faktor risiko yang paling bermakna menyebabkan underweight adalah kehilangan gigi lebih dari atau sama dengan 16 gigi, asupan lemak dan karbohidrat yang kurang, serta pendapatan kurang dari Rp 808.000,00.

Berdasarkan simpulan tersebut, maka perlu adanya peningkatan usaha promotif dan preventif terutama pada bidang gizi, gigi, dan mulut oleh petugas kesehatan puskesmas. Bagi peneliti selanjutnya, 
perlu dipertimbangkan penggunaan alat ukur tingkat kecemasan yang tepat untuk lansia dan penggalian data asupan makan melalui metode SQFFQ dengan didukung metode lain, misalnya food record sehingga dapat lebih meminimalisir terjadinya bias informasi. Selain itu, perlunya mengontrol variabel pendapatan dalam menilai risiko status kesehatan dan asupan makan terhadap underweight.

\section{RUJUKAN}

1. BPS (Badan Pusat Statistik). Statistik penduduk lanjut usia. Jakarta: BPS; 2010.

2. Fatmah. Gizi usia lanjut. Jakarta: Erlangga; 2010.

3. Dinas Kesehatan Provinsi DIY. Profil kesehatan provinsi D.I Yogyakarta tahun 2009. Yogyakarta: Dinkes DIY; 2010.

4. BPS Provinsi DIY. Daerah Istimewa Yogyakarta dalam angka 2010. Yogyakarta: BPS DIY; 2010.

5. Barasi ME. At a glance ilmu gizi. Jakarta: Penerbit Erlangga; 2009.

6. Hutton $\mathrm{B}$, Feine $\mathrm{J}$, Morais $\mathrm{J}$. Is there an association between edentulism and nutritional state?. J Can Dent Assoc 2002;68(3):182-7.

7. Balitbangkes Depkes RI. Hasil riset kesehatan dasar (RISKESDAS) 2007. Jakarta: Departemen Kesehatan Republik Indonesia; 2008.

8. Niken-Sriyono. Pencegahan penyakit gigi dan mulut guna meningkatkan kualitas hidup. Naskah dipresentasikan dalam Rapat Terbuka Majelis Guru Besar Universitas Gadjah Mada. Yogyakarta: Universitas Gadjah Mada; 2009.

9. Arifin. Hubungan kesehatan mulut dan status gizi dengan kualitas hidup lansia (Tesis). Yogyakarta: Universitas Gadjah Mada; 2011.

10. Vir SC, Love AH. Nutritional status of institutionalized and noninstitutionalized aged in Belfast, Northern Ireland. Am J Clin Nutr 1979;32(9):1934-47.

11. Morley JE, Silver AJ. Nutritional issues in nursing home care. Ann Intern Med 1995;123(11):850-9.

12. Fatmah. Respon imunitas yang rendah pada tubuh manusia usia lanjut. Makara Kesehatan 2006;10(1):4753.

13. Funderburg KM, Mathews MK. Special topics in age-related risks: unique nutrition issues in the older adult. In: Sharlin J, Edelstein S. Essentials of life cycle nutrition. USA: Jones and Barlett Publishers; 2011.
14. Schlesselman JJ. Case-control study (design, conduct, analysis). New York: Oxford University Press; 1982.

15. Beck JD, Arbes.Jr SJ. Epidemiology of gingival and periodontal diseases. In: Newman MG, Takei HH, Carranza FA, editors. Carranza's clinical epidemiology. 9th ed. Philadelphia: W.B. Saunders Company; 2002.

16. Cahyati WH. Beberapa faktor yang berhubungan dengan karies gigi pada lanjut usia (Studi kasus di Panti Wreda Kota Semarang). Kemas 2005;1:22-30.

17. Woodall IR, Dafoe BR, Young NS, Weed-Fonner L, Yankell SL. Comprehensive dental hygiene care. St Louis: The CV Mosby Company; 1985.

18. Rabe B, Thamrin MH, Gross R, Solomons NW, Schultink $W$. Body mass index of the elderly derived from height and from armspan. Asia Pac J Clin Nutr 1996;5(2):79-83.

19. Dirjen Yankes Depkes RI. Profil kesehatan gigi dan mulut di Indonesia pada pelita VI. Jakarta: Depkes $\mathrm{RI} ; 2000$.

20. Wangsarahardja K, Dharmawan OV, Kasim E. Hubungan antara status kesehatan mulut dan kualitas hidup pada lanjut usia. Universa Medicina 2007;26(4):186-94.

21. Wibisono A, Ghozali TD. Kebutuhan gigi palsu pada usia lanjut. Dalam: Martono H, Pranaka K, editor. Buku ajar Boedhi-Darmojo geriatri (ilmu kesehatan lansia). Edisi ke-4. Jakarta: Balai Penerbit FKUI; 2010.

22. Tampubolon NS. Dampak karies gigi dan penyakit periodontal terhadap kualitas hidup. Naskah dipresentasikan dalam Rapat Terbuka Majelis Guru Besar Universitas Sumatera Utara. Medan: Universitas Sumatera Utara; 2005.

23. Chatrchaiwiwatana S. Factors affecting tooth loss among rural Khon Kaen adults: analysis of two data sets. Public Health 2007;121(2):106-12.

24. Hidayati S, Mu'afiro A, Suwito J. Analisis faktor yang berhubungan dengan tingkat keparahan periodontitis pada penderita DM tipe 2 di poli diabetes RSU dr. Soetomo Surabaya. Buletin Penelitian RSU Dr. Soetomo 2008;10(2):49-54.

25. Paratmanitya $Y$, Hadi $H$, Susetyowati. Citra tubuh, asupan makan, dan status gizi wanita usia subur pranikah. Jurnal Gizi Klinik Indonesia 2012;8(3):126-34.

26. Almatsier $S$, Soetarjo $S$, Soekatri M. Gizi seimbang dalam daur kehidupan. Jakarta: Gramedia Pustaka Utama; 2011. 